UDC 32.001:39

Torsten J. SELCK,

Lilit BAGHDASARYAN

\title{
FRACTIONALIZATION OF UNRECOGNIZED STATES IN EUROPE
}

(This research received no specific grant from any funding agency in the public, commercial, or not-for-profit sectors)

\begin{abstract}
Aims: The data on ethnic fractionalization is out-of-date in some cases, and in the case of some countries there are no such data at all. We measure the ethnic, linguistic and religious fractionalization of unrecognized states in Europe -of Abkhazia, Northern Cyprus, Nagorno-Karabakh, Transnistria and Kosovo, which were up till now excluded from the scope of interest of fractionalization observers. Methods: Using the population census data of these countries, we measure the fractionalization with the one minus Herfindahl index. Results: Whether homogenous or heterogeneous, the levels of their fractionalization remain different. Therefore, the (non)recognition of a state has no effect on its level of fractionalization.
\end{abstract}

Keywords: fractionalization, unrecognized states.

Introduction

It is almost impossible to find a concrete definition of the term „unrecognized states". The so-called "nonexistence" of these states means that they de jure don't have "international recognition", which in turn leads to the fact that the de facto existing states or the new "state associations" remain out of "lists" of states and are not examined.We use the definition of Caspersen N. (2012), which states that "unrecognized states are the places that do not exist in international relations; they are state-like entities that are not part of the international system of sovereign states; consequently they are shrouded in mystery and subject to myths and simplifications". Caspersen (2012) has created a dataset of unrecognized states since World War II. Based on this list, we selected all the unrecognized states in Europe.

Studies of ethnicity and ethnic fractionalization have become increasingly prominent in recent years and are being used as basis for cross country comparisons. Most research using ethnicity or ethnic fractionalization as a variable assesses neither the precision nor the age of data, there by contributing to the incompleteness of any data obtained. The focus is mostly on the combined data containing two different variables rather than on the up-to-date data of ethnic fractionalization itself. The data of ethnic fractionalization is out-of-date in some cases, and for other cases there are no such data at all. The rationale for this can be the "nonexistence" of these states.

The data on the populations living in these areas are not included in the database of provisionally called "parent" states, and this also reduces the accuracy of the examined data of those "existing" states. 
These countries are also notmonitored and recognized as a separate unit. As a result, we have problem areas even on the map of 'advanced' Europe.

To measure the fractionalization of states that have so far been ignored by previous fractionalization observers we use the classic one minus the Herfindahl index. In addition to ethnic and linguistic fractionalization, we also measure the religious fractionalization of The Turkish Republic of Northern Cyprus, The Republic of Kosov, Abkhazia, Nagorno-Karabakh, and Transnistria, which, due to political or international legal controversies, were barred from acceptance as part of the 'civilized world'.

In order to avoid spurious data our research excludes the Donetsk and Lugansk People's Republics.Even though they are in Europe and declared their independence in May 2014,they are still sufferingactive hostilities, which in turn hashad a decisive impact on both human migration and ethnic composition.

Due to the lack of existing census data, we also do not calculate the fractionalization of the Republic of South Ossetia, where the last population census was held in the Soviet era (1989). There is also no data for South Ossetia in the Pan-Russian population census of 2002. Although it was still under Moscow's political influence in 2002, it nevertheless considered itselfa part of Georgia (the 2002 census of Georgia also does not provide any information about the ethnicity, language or religion in South Ossetia).

\section{Existing literature}

Ethnicity is a common variable in investigations of democracy, economic inequality, civil war, education, life expectancy etc. Alesina et al. (2003) provide a new index for measuring ethnic, linguistic and religious fractionalization in 190 countries. This paper has become a basis for many fractionalization studies, e.g. Campos and Kuzeyev (2007), which update the ethnic fractionalization data for 26 former communist countries and found that ethnic fractionalization is negatively related to growth. Bossert et al. (2006) build a new index - the generalized ethno-linguistic fractionalization index - arguing that it is more flexible than the commonly used ethno-linguistic fractionalization index (ELF) and can also be applied to non-state cases e.g. industrial organizations. Posner (2004) creates the index of politically relevant ethnic groups (PREG) arguing that most measures of ethnic diversity are inappropriate for testing the impact of ethnic diversity on economic growth. The Distance Adjusted ethno-linguistic fractionalization index developed by Kolo (2012) measures different aspects of ethnicity for 210 countries and focuses on the (dis)similarities between ethnic groups. Laitin and Posner (2001) criticize the standard ELF index and Reynal-Querol (2002) analyzes the effect of ethnic division on civil war and the role of political systems in preventing these conflicts. Montalvo and Reynal-Querol (2002) build their index on polarization and argue that this has a positive effect on civil wars. The relationship of ethnicity, ethnic fractionalization and civil war was also studied by Cederman and Girardin (2007) who argue that "specific ethno-nationalist configurations are more prone to generate violence in civil wars". (173)

To measure ethnic and linguistic fractionalization Hudson and Taylor (1972) use the index from Rae and Taylor (1970), who have calculated party cleavages in legislative seats and original votes cast. Alesina et al. (2003) measure the ethnic, linguistic and religious fractionalization in 190 countries and create a new database using a similar index - the one minus the Herfindahl index.

Recently, researchers have paid increasing attention to unrecognized states which were formed in the 1990s as a result of ethnic conflict. Various authors examine their internal and external relationships, 
their history of recognition and their process towards a possible recognition. Protsyk (2012) discusses the political system of Transnistria. King (2001) viewed the educational and cultural institutions, the external relations and also the economic situation of Eurasian unrecognized states (Nagorno-Karabakh, Transnistria, Abkhazia, Ossetia). Bolshakov and Mansurov (2013) discuss the causes of conflict in the unrecognized states of the South Caucasus and come to the conclusion that "the settlement of the conflicts of identities in the region greatly depends on the formation of a national idea based on pragmatic approach to national development by a state, which assumes taking into account and supporting cultural, ideological and political versatility" (47).

Blakkisrud\&Kolstø (2012) examined the internal and external political behavior of unrecognized states in the South Caucasus and undertake a comparative analysis of how these statelets have attempted to consolidate statehood though processes of state- and nation-building (2008). They also focus on the example of Nagorno-Karabakh, namely by discussing its democracy with reference to a list of the factors influencing it - cultural homogeneity, size, existential threats, and role of the diaspora (2012). Based on official sources, interviews and political science literature they study the Transnistria conflict and the options available for its recognition as a state (2011).

The fractionalization of unrecognized states in Europe and its bordering countries has, however, still not been studied.

\section{Data}

The main data source of the authors who have examined fractionalization is the same: Alesina et al. (2003) and Fearon (2003) use the data from Encyclopedia Britannica and the CIA World Factbook while Posner (2004) translates Atlas Narodov Mira (1964) from Russian. All the missing data these authors took from the corresponding census data.

There is no data for our group of countries in any of these sources. Data for the provisionally called "mother" states are available from Alesina et al. (2003), according to whom it is impossible to get an insight about the unrecognized states in that area.

Because none of the above mentioned sources have data for our group of countries, the last census data in these countries has served as the main (and only) source for our research.

The study of the questionnaires of the censuses of unrecognized states shows that there are many differences between the questions. In the case of some countries there is no question about religious adherence. In other countries there is no question of what language the people speak or what their mother tongue is. The lack of these data have unfortunately had a negative impact on our research and as a result we study only the ethnic and religious fractionalization (without the linguistic fractionalization) of Abkhazia, Northern Cyprus, Transnistria and the ethnic and linguistic fractionalization (without the religious one) of Nagorno-Karabakh. In the case of Kosovo we measure all 3 fractionalizations.

Because the population censuses in these countries were conducted in the period between 2004 and 2011, our study primarily covers this period. 


\section{Method}

To measure the fractionalization in 190 countries Alesina et al. (2003) use the classic one minus the Herfindahl index of ethnolinguistic group shares, in which two randomly selected individuals from a population belong to different groups, and apply it to different underlying data. ${ }^{1}$

For our study we also use this index and apply it to measure the ethnic and religious and in two cases also the linguistic fractionalization of unrecognized states:

$$
F R A C T_{j}=1-\sum_{i=1}^{N} S_{i, j}^{z}
$$

where $S_{i j}$ is the share of group $i(i=1 \ldots N)$ in country $j$. The index varies from 0 (completely homogeneous society) to 1 (every member of society is a separate group).

\section{Fractionalization}

Based on our fractionalization database (Table: 1), we classify our group of countries according to the spreadsheet of fractionalization examples developed by Fearon (2003), where A-class countries are considered to be perfectly homogeneous, and H-class and I-class countries are the most heterogeneous. According to this spreadsheet, in terms of the ethnic fractionalization Nagorno-Karabakh is perfectly homogeneous - 99,74 \% of its population is Armenian. Nagorno-Karabakh is also perfectly homogeneous in terms of linguistic fractionalization with $99 \%$ of Armenian language speakers. From the religious point of view Northern Cyprus and Kosovo are perfectly homogeneous, with respectively $98 \%$ Muslim and 92,72 \% Sunni Muslim citizens.

Fearon (2003: 208) argues that the fractionalization scores for countries $E$ and $F$ (respectively with average values of 0.67 and 0.59 ) are not that different. The ethnicity and religion of Abkhazia and the ethnicity of Northern Cyprus belong to these classes.

The most ethnically heterogeneous country isTransnistria and the most heterogeneous in religious terms is Abkhazia.

If we apply the theory of Fearon, countries with the average value of 0.48 (Ibid.: 209) to the example of ethnic fractionalization in Northern Cyprus, there is about a 50-50 chance that two randomly selected people would come from different groups: The ethnic fractionalization of Northern Cyprus is 0.46 , with $66,7 \%$ of the population being TRNC, 29, $29 \%$ Turks, and 3,99 \% other ethnic groups.

Table 1: Ethnic, linguistic and religious fractionalization scores:

\begin{tabular}{|l|c|c|c|c|}
\hline Country/ source of data & Census & $\begin{array}{c}\text { Ethnic } \\
\text { fractionalization }\end{array}$ & $\begin{array}{c}\text { Linguistic } \\
\text { fractionalization }\end{array}$ & $\begin{array}{c}\text { Religious } \\
\text { fractionalization }\end{array}$ \\
\hline Abkhazia & 2011 & 0.656 & - & 0.598 \\
\hline Kosovo & 2001 & 0.135 & 0.105 & 0.0852 \\
\hline Nagorno-Karabakh & 2005 & 0.005 & 0.0197 & - \\
\hline Northern Cyprus & 2006 & 0.467 & - & 0.0392 \\
\hline Transnistria & 2004 & 0.720 & - & 0.184 \\
\hline
\end{tabular}

\footnotetext{
${ }^{1}$ Hudson and Taylor (1972) use a quite similar index to measure the ethnic and linguistic fractionalization:$$
F=1-\sum_{i=1}^{n}\left(\frac{n_{i}}{N}\right)\left(\frac{n_{i}-1}{N-1}\right)
$$ 
Source: Authors' calculations.

\section{Conclusion}

We believe we are the first to study the fractionalization of unrecognized states in Europe. Measuring the fractionalization with the one minus Herfindahl index has shown that, whether or not unrecognized states are as perfectly homogeneous as Nagorno-Karabakh or as fully heterogeneous as Transnistria, the fractionalization levels of the unrecognized states remain different. When Taylor and Hudson measured the ethno-linguistic fractionalization of a large group of countries, they aimed to help researchers "in their triple functions of explaining, predicting, and evaluating political behavior» (1972: 3). Measuring fractionalization in unrecognized states, we also aim to build a basis for further research about their political behavior, economy, democracy, and potential for recognition.

\section{REFERENCES}

Alesina, A., Devleeschauwer A., Easterly W., Kurlat S., and WacziargR. (2003). "Fractionalization." Journal of Economic Growth8 (2): 155-194.

Atlas narodov mira (Atlas of the world's peoples). 1964. Glavnoe upravlenie geodezii i kartografii gosudarstvennogo geologicheskogo komiteta SSSR institute Etnografii im. N.N.Miklukho-Maklaya. Moskva.

Blakkisrud, H., Kolst $\varnothing$, P. (2008). "Living with Non-recognition: State- and Nation-building in South Caucasian Quasi-states." Europe-Asia Studies 60 (3): 483-509.

Blakkisrud, H., Kolst $\varnothing$, P. (2011). "From Secessionist Conflict Toward a Functioning State: Processes of State- and Nation-Building in Transnistria." Post-Soviet Affairs 27 (2): 178-210.

Blakkisrud, H., Kolst $\varnothing$, P. (2012). "Dynamics of de facto statehood: the South Caucasian de facto states between secession and sovereignty." Southeast European and Black Sea Studies 12 (2): 281-298.

Blakkisrud, H., Kolst $\varnothing$, P. (2012). "De facto states and democracy: The case of Nagorno-Karabakh." Communist and Post-Communist Studies 45 (1-2): 141-151.

Bolshakov, A., Mansurov, T. (2013). "Conflicts of identities in the South Caucasus and problems of integration of the states of the region into European structures." World Applied Sciences Journal 27: 43-47.

Bossert, W., D’Ambrosio, C. and La Ferrara, E. (2011). "A Generalized Index of Fractionalization." Economica 78: 723-750.

Campos, N., Kuzeyev, V. "On the Dynamics of Ethnic Fractionalization." American Journal of Political Science 51(3): 620-639.

Caspersen, N. (2012). "Unrecognized States: The Struggle for Sovereignty in the Modern International System." Campridge: Polity.

Cederman, L.E., Girardin, L. (2007). "Beyond Fractionalization: Mapping Ethnicity onto Nationalist Insurgencies." American Political Science Review 101: 173-185.

Fearon, J. (2003). "Ethnic and Cultural Diversity by Country." Journal of Economic Growth 8 (2): 195-222. Kanchan, Ch., Wilkinson, S. (2008). "Measuring the Effect of Ethnicity." Comparative Political Studies 41: 515-563. 
King, Ch. (2001). "The Benefits of Ethnic War: Understanding Eurasia's Unrecognized States." World Politics 53 (4): 524-552.

Kolo, Ph. (2012). "Measuring a New Aspect of Ethnicity - The Appropriate Diversity Index." Ibero-America Institute for Economic Research.University Göttingen. Discussion Papers: 221.

Laitin, D., Posner, D.N. (2001). "The Implications of Constructivism for Constructing Ethnic Fractionalization Indices." APSA-The Comparative Politics Newsletter 12: 13-17.

Montalvo, J.G., Reynal-Querol, M. (2002). "Why Ethnic Fractionalization? Polarization, Ethnic Conflict and Growth." UniversitatPompeuFabra, Economics Working Paper: No. 660.

Posner, D. (2004). "Measuring Ethnic Fractionalization in Africa." American Journal of Political Science. 48 (4): 849-863.

Protsyk, O. (2012). "Secession and hybrid regime politics in Transnistria." Communist and Post Communist Studies 45 (1-2): 175-182.

Reynal-Querol, M. (2002). "Ethnicity, political systems, and civil wars."Journal of Conflict Resolution 46 (1): $29-54$.

Taylor, C. and M. Hudson, (1972). World Handbook of Political and Social Indicators.

Sources of census data:

Abkhazia/ http://abkhazia.gov.ge/

Kosovo/https://ask.rks-gov.net/eng/

Nagorno-Karabakh/ http://www.stat-nkr.am/en/national-statistical-service-of-nkr

Northern Cyprus/

http://www.devplan.org/Frame-eng.html 